\title{
Ochrona pracy osób niepełnosprawnych
}

\author{
Ewa Staszewska \\ Uniwersytet Łódzki \\ estaszewska@wpia.uni.lodz.pl \\ ORCID: https://orcid.org/0000-0002-5807-4630
}

Punktem wyjścia niniejszego opracowania jest art. 24 Konstytucji RP, z którego wynika, że praca znajduje się pod ochroną Rzeczypospolitej Polskiej, a państwo sprawuje nadzór nad warunkami jej wykonywania. W przywołanym przepisie określona została zasada ochrony pracy i nadzoru przez państwo nad warunkami jej wykonywania. Z zasady tej wynika obowiązek stwarzania przez państwo gwarancji ochrony pracowników (jako słabszej strony stosunku pracy), w tym ochrony przed niezgodnymi z prawem lub nieuzasadnionymi działaniami pracodawcy oraz kontroli przestrzegania przepisów prawa pracy $^{1}$.

$\mathrm{W}$ doktrynie prawa konstytucyjnego przez pojęcie ochrony pracy rozumie się podejmowanie środków prawnych, politycznych i faktycznych, których celem jest osłabienie negatywnych skutków, jakie dla pracowników niesie silniejsza pozycja ekonomiczna pracodawcy. Sprawowanie ochrony jest równoznaczne z obowiązkiem ingerowania przez państwo $\mathrm{w}$ stosunki między pracownikami i pracodawcami, gdy jest to niezbędne dla zapewnienia należytej równowagi uczestników procesu pracy $^{2}$. Wartością chronioną $\mathrm{w}$ art. 24 Konstytucji jest praca rozumiana jak najszerzej, niezależnie od form prawnych, w jakich jest wykonywana. Nie oznacza to jednak, jak słusznie zauważa Arkadiusz Sobczyk ${ }^{3}$, że objęcie ochroną każdej pracy jest równoznaczne z ochroną jednakową.

1 Wyrok TK z dnia 4 października 2005 r., K 36/03. Szeroko na ten temat: T. Liszcz, Konstytucyjna zasada ochrony pracy, [w:] Prawo pracy. Refleksje i poszukiwania. Księga Jubileuszowa Profesora Jerzego Wratnego, red. G. Uścińska, Warszawa 2013, s. 34 i n.

2 L. Garlicki, Komentarz do art. 24 Konstytucji, [w:] Konstytucja Rzeczypospolitej Polskiej. Komentarz. Tom I, red. L. Garlicki, M. Zubik, Warszawa 2016, Lex/el.

3 A. Sobczyk, Prawo pracy w świetle Konstytucji RP. Tom I. Teoria publicznego i prywatnego indywidualnego prawa pracy, Warszawa 2013, s. 52 
Konstytucyjna zasada ochrony pracy realizowana jest przez państwo przede wszystkim przez stanowienie właściwego ustawodawstwa chroniącego osoby pracujące. Choć obowiązek ochrony pracy powinien być realizowany poprzez przepisy kierowane do jak najszerszego kręgu osób wykonujących pracę (zarówno w ramach pracowniczych, jak i niepracowniczych form zatrudnienia), to jednak aktualnie najpełniej chronioną grupą są osoby świadczące pracę $\mathrm{w}$ ramach reżimu prawa pracy. Pojęcie „ochrony pracy” w nauce prawa pracy jest powszechnie używane, ale należy zaznaczyć, że charakteryzuje je dyferencjacja ujęć, zwłaszcza jeśli chodzi o zakres przedmiotowy ${ }^{4}$. W konsekwencji oznacza to, iż posługiwanie się tym pojęciem wymaga ustalenia jego zakresu. Wacław Szubert jako przedmiot ochrony pracy traktował zabezpieczenie pracownika przed szkodliwym oddziaływaniem środowiska pracy na jego zdrowie i przed zagrożeniem życia ${ }^{5}$. Opowiadał się za szerokim rozumieniem ochrony pracy jako ogółu środków prawnych, ekonomicznych i technicznych, służących zapewnieniu bezpiecznych i higienicznych warunków pracy. Ochronę pracy odnosił również do instytucji czasu pracy i urlopów wypoczynkowych ${ }^{6}$. Teresa Liszcz do trzonu prawa ochrony pracy zalicza przepisy o bezpieczeństwie i higienie pracy oraz przepisy o szczególnej ochronie pracy kobiet i młodocianych. Zdaniem autorki do prawa ochrony pracy należy także zaliczyć przepisy o nadzorze nad przestrzeganiem prawa pracy przez pracodawców, o odpowiedzialności pracodawców za naruszenia praw pracowników, a także prawo urlopowe i prawo o czasie pracy, które także winny mieć na względzie głównie ochronę życia i zdrowia pracownika ${ }^{7}$.

Szczególnego znaczenia ochrona pracy nabiera z punktu widzenia jej zakresu podmiotowego, a zatem ochrona pracy wybranych, szczególnych grup pracowników. Pomimo wykonywania nawet jednakowej pracy związane z nią zagrożenia nie zawsze będą takie same dla wszystkich pracowników. Co więcej, niektóre rodzaje prac lub warunki pracy mogą okazać się zbyt dużym obciążeniem dla określonych grup pracowników. Biorąc pod uwagę powyższe, wyodrębnia się powszechną i szczególną ochronę pracy. Powszechna ochrona pracy realizowana jest przez przepisy odnoszące się do wszystkich pracowników. Z kolei szczególna ochrona pracy odnosi się do osób, których zdolność do pracy oraz zdrowie ze względu na funkcje biologiczne oraz właściwości psychofizyczne powinny podlegać specjalnej pieczy ${ }^{8}$.

4

Szeroko na ten temat A. Sobczyk, Wątpliwości co do użyteczności stosowania pojęcia „ochrona pracy”, [w:] Prawo ochrony pracy - współczesność i perspektywy rozwoju, red. T. Wyka, M.A. Mielczarek, Warszawa 2017, s. 46 i n.

W. Szubert, Ochrona pracy, [w:] Z. Salwa, W. Szubert, M. Święcicki, Podstawowe problemy prawa pracy, Warszawa 1957, s. 98 i n.

W. Szubert, Uwagi o pojęciu ochrony pracy, [w:] Rozprawy prawnicze. Księga pamiątkowa dla uczczenia pracy naukowej Kazimierza Przybyłowskiego, Kraków-Warszawa 1964, s. 380 i n.

T. Liszcz, Konstytucyjne podstawy ochrony pracy, [w:] Prawo ochrony pracy - współczesność i perspektywy rozwoju, red. T. Wyka, M.A. Mielczarek, Warszawa 2017, s. 63; T. Liszcz, Prawo pracy, Warszawa 2009, s. 393. T. Kuczyński, Ochrona pracy, [w:] Z. Kubot et al., Prawo pracy. Zarys wykładu, Warszawa 2008, s. 277. 
Trudno ustalić zamknięty katalog pracowników, których należy objąć szczególną ochroną pracy. Najczęściej wymieniane są kobiety, młodociani oraz osoby niepełnosprawne ${ }^{9}$, których status z w zakresie wzmożonej ochrony ich pracy jest przedmiotem niniejszego opracowania.

Należy tu wyjaśnić, kto w polskim systemie prawa może uzyskać status osoby niepełnosprawnej ${ }^{10}$, a co za tym idzie może korzystać ze szczególnej ochrony w razie podjęcia pracy. Zgodnie $\mathrm{z}$ art. 1 ustawy z dnia 27 sierpnia 1997 r. o rehabilitacji zawodowej i społecznej oraz zatrudnianiu osób niepełnosprawnych ${ }^{11}$ osobami niepełnosprawnymi są osoby posiadające określone rodzaje orzeczeń potwierdzających niepełnosprawność, przez którą należy rozumieć trwałą lub okresową niezdolność do wypełniania ról społecznych z powodu stałego lub długotrwałego naruszenia sprawności organizmu, w szczególności powodującą niezdolność do pracy (art. 2 pkt 10 u.r.z.s.n.). Niepełnosprawność może zostać potwierdzona jednym $\mathrm{z}$ trzech rodzajów orzeczeń, które zostały wymienione w art. 1 u.r.z.s.n.

Pierwszy rodzaj orzeczeń to orzeczenia o jednym z trzech stopni niepełnosprawności, wydawane przez zespoły do spraw orzekania o niepełnosprawności. Dla realizacji celów określonych ustawą o rehabilitacji prawodawca wprowadził trzy stopnie niepełnosprawności: znaczny, umiarkowany oraz lekki ${ }^{12}$. Drugi rodzaj to orzeczenia o całkowitej lub częściowej niezdolności do pracy, wydane na podstawie odrębnych przepisów. Chodzi tutaj o orzeczenia wydawane na gruncie ustawy z dnia 17 grudnia 1998 r. o emeryturach i rentach z Funduszu Ubezpieczeń Społecznych ${ }^{13}$. Orzeczenia lekarza orzecznika Zakładu Ubezpieczeń Społecznych są równoważne $\mathrm{z}$ odpowiednimi orzeczeniami o znacznym, umiarkowanym bądź lekkim stopniu niepełnosprawności ${ }^{14}$. Trzeci rodzaj to orzeczenia o niepełnospraw-

9 Tak m.in. T. Kuczyński, Ochrona pracy..., s. 277; M. Tomaszewska, Powszechna ochrona pracy, [w:] J. Stelina, Prawo pracy, Warszawa 2014, s. 564.

10 Należy zauważyć, że polski ustawodawca posługuje się pojęciem „osób niepełnosprawnych”, podczas gdy odchodzi się od takiej terminologii na rzecz pojęcia „osób z niepełnosprawnościami”. Ratyfikowana przez Polskę Konwencja ONZ o prawach osób niepełnosprawnych z dnia 13 grudnia 2006 r. (Dz.U. z 2012 r. poz. 1169) w języku angielskim brzmi: Convention on the Rights of Persons with Disabilities, a zatem Konwencja o prawach osób z niepełnosprawnościami. Por też. K. Kurowski, Niepełnosprawność i osoba niepełnosprawna - od medycznego do społecznego modelu niepełnosprawności, [w:] Najważniejsze wyzwania po ratyfikacji Konwencji o Prawach Osób Niepełnosprawnych, red. A. Błaszczak, „Biuletyn RPO. Żródła” 2012, nr 10, s. 8 i n.; M. Paluszkiewicz, Wolność pracy osób z niepełnosprawnościami jako wartość prawnie chroniona, Łódź 2019, s. 42; M. Giełda, Pojęcie niepełnosprawności, [w:] Prawno-administracyjne aspekty sytuacji osób niepełnosprawnych w Polsce, red. M. Giełda, R. Raszewska-Skałecka, Wrocław 2015, s. 25.

11 Zob. tekst jedn. Dz.U. z 2020 r. poz. 426, dalej jako u.r.z.s.n.

12 A. Tyśkiewicz-Mazur, Definicje niepełnosprawności na potrzeby rehabilitacji zawodowej i zatrudnienia, [w:] A. Giedrewicz-Niewińska, M. Szabłowska-Juckiewicz, Zatrudnianie osób niepełnosprawnych. Regulacje prawne, Warszawa 2014, s. 45.

13 Zob. tekst jedn. Dz.U. z 2020 r. poz. 53.

14 Patrz art. 5 u.r.z.s.n. 
ności wydane przed ukończeniem 16. roku życia ${ }^{15}$. Ponadto, zgodnie z art. 62 ust. 2 pkt 1 u.r.z.s.n., osobami niepełnosprawnymi są również osoby, które przed dniem wejścia w życie ustawy zostały zaliczone do jednej z grup inwalidów, jeżeli przed tą datą orzeczenie o zaliczeniu do jednej $\mathrm{z}$ grup inwalidów nie utraciło mocy ${ }^{16}$. Ustawodawca nie pozostawia wątpliwości, iż warunkiem posiadania statusu osoby niepełnosprawnej jest uzyskanie stosownego orzeczenia potwierdzającego niepełnosprawność. Nie jest zatem możliwe uznanie za niepełnosprawną osoby $\mathrm{z}$ faktycznymi ograniczeniami w funkcjonowaniu, nawet znaczącymi i widocznymi, jeżeli nie legitymuje się ona stosownym orzeczeniem ${ }^{17}$.

Jednym z najważniejszych aspektów życia każdego człowieka jest możliwość wykonywania pracy, która pozostaje w ścisłym związku z godnością osoby ludzkiej, decyduje o pozycji człowieka w społeczeństwie, stanowiąc podstawę jego egzystencji materialnej. Odwołując się do uwarunkowań aksjologicznych, trzeba uznać, iż praca przedstawia dla człowieka samoistną wartość, nie będąc jedynie sposobem zaspakajania takich czy innych potrzeb, ale sama jest potrzebą i przeznaczeniem. Pogląd ten wydaje się dość silnie zakorzeniony w naszym kręgu cywilizacyjnym ${ }^{18}$. Takie postrzeganie pracy czyni ją dobrem pożądanym przez każdego człowieka każdy winien mieć możliwość jej wykonywania, każdy winien mieć prawo do pracy. Niepełnosprawność może powodować jednak negatywne konsekwencje w zakresie zdolności do wykonywania pracy zarobkowej. Stąd też niezbędne są środki prawne wspierające pełne uczestnictwo społeczne i zawodowe osób posiadających tę cechę, pozwalające urzeczywistnić prawo do pracy osób niepełnosprawnych. Będzie to prawne instrumentarium, które finalnie ma pomóc w pozyskaniu i utrzymaniu zatrudnienia, na jakie składa się także konieczność tzw. wzmożonej ochrony pracy osób niepełnosprawnych - w maksymalnie szerokim znaczeniu. Ochrona pracy osób niepełnosprawnych wymaga podjęcia działań, które z jednej strony zapobiegną pogłębianiu się niepełnosprawności, a z drugiej wyrównają istniejące deficyty i zapewnią tym pracownikom komfortowe warunki pracy ${ }^{19}$. Polski ustawodawca realizuje ochronę pracy osób niepełnosprawnych, nakładając na pracodawców szczególne obowiązki wobec pracowników niepełnosprawnych, które są wyrażone przede wszystkim w ustawie z dnia 27 sierpnia 1997 r. o rehabilitacji zawodowej i społecznej oraz zatrudnianiu osób niepełnosprawnych, jak również w Kodek-

15 M. Paluszkiewicz, [w:] Ustawa o rehabilitacji zawodowej i społecznej oraz zatrudnianiu osób niepełnosprawnych. Komentarz, red. M. Włodarczyk, Warszawa 2015, s. 32 i n.

16 W art. 62 ust. 2 określona została równoważność orzeczeń o zaliczeniu do I, II, III grupy inwalidów z orzeczeniem o znacznym, umiarkowanym bądź lekkim stopniu niepełnosprawności.

17 I. Sierpowska, Pojęcie niepełnosprawności i procedury orzekania o niepełnosprawności, [w:] I. Sierpowska,

A. Kogut, Status osoby niepełnosprawnej w polskim systemie prawa, Wrocław 2010, s. 35.

18 Z. Góral, Prawo do pracy. Studium prawa polskiego w świetle porównawczym, Łódź 1994, s. 10.

19 M. Paluszkiewicz, Ujawnianie orzeczenia o niepełnosprawności a realizacja obowiązku ochrony zdrowia i życia pracownika z niepełnosprawnością - wybrana problematyka, [w:] Prawo ochrony pracy - współczesność i perspektywy rozwoju, red. T. Wyka, M.A. Mielczarek, Warszawa 2017, s. 321. 
sie pracy $^{20}$. Na wzmożoną ochronę pracy osób niepełnosprawnych składają się bez wątpienia określone obowiązki z zakresu zapewnienia bezpiecznych i higienicznych warunków pracy, ale także specjalne regulacje dotyczące czasu pracy czy urlopów wypoczynkowych.

Prawo do bezpiecznych i higienicznych warunków pracy jest prawem o charakterze powszechnym, zagwarantowanym w art. 66 ust. 1 Konstytucji, stanowiąc również jedną z podstawowych zasad prawa pracy, wskazanych w art. $15 \mathrm{kp} .{ }^{21}$ Pracownicy niepełnosprawni mają zatem prawo do bezpiecznych i higienicznych warunków pracy przede wszystkim na zasadach odnoszących się do wszystkich pracowników ${ }^{22}$. Analiza poszczególnych regulacji prawnych $\mathrm{z}$ tego zakresu pozwala jednak zauważyć wzmożoną ochronę pracowników z niepełnosprawnościami.

Z art. $207 \$ 2 \mathrm{kp}$. wynika, że pracodawca jest obowiązany chronić zdrowie i życie pracowników przez zapewnienie bezpiecznych i higienicznych warunków pracy przy odpowiednim wykorzystaniu osiągnięć nauki i techniki. Formułując ten generalny obowiązek pracodawcy ochrony zdrowia i życia pracowników, ustawodawca wskazał jednocześnie na obowiązek szczegółowy dotyczący pewnych działań profilaktycznych, adresowanych do grup szczególnego ryzyka ${ }^{23}$. Otóż zgodnie z art. 207 $\$ 2$ kp. pracodawca jest zobowiązany uwzględniać ochronę zdrowia pracowników niepełnosprawnych $\mathrm{w}$ ramach podejmowanych działań profilaktycznych. Biorąc pod uwagę właściwości psychofizyczne pracowników niepełnosprawnych, są oni zaliczani do grup szczególnego ryzyka, co znalazło wyraz w art. 6 ust. 1 pkt $2 \mathrm{~g}$ ustawy z dnia 27 czerwca 1997 r. o służbie medycyny pracy ${ }^{24}$.

Ustawa o rehabilitacji zawodowej i społecznej oraz zatrudnianiu osób niepełnosprawnych w zakresie bezpieczeństwa i higieny pracy przewiduje dodatkowe regulacje związane $\mathrm{z}$ uprawnieniami pracowników niepełnosprawnych do pracy na przystosowanym stanowisku pracy. Kwestia ta została ujęta w kilku miejscach ustawy - w zależności od tego, czy dotyczy pracodawców zapewniających, czy niezapewniających warunki pracy chronionej, co jest konsekwencją możliwości zatrudniania pracowników niepełnosprawnych na otwartym rynku pracy bądź w zakładach pracy chronionej i zakładach aktywności zawodowej. W pierwszym

20 Ustawa z dnia 26 czerwca 1974 r. Kodeks pracy (tekst jedn. Dz.U. z 2019 r. poz. 1040), dalej jako kp.

21 Szeroko na ten temat: Z. Góral, O kodeksowym katalogu zasad indywidualnego prawa pracy, Warszawa 2011 , s. $190 \mathrm{in}$.

22 P. Majka, M. Rydzewska, I. Wieleba, Zatrudnianie osób niepełnosprawnych. Aspekty prawne i podatkowe, Warszawa 2018, s. 154.

23 T. Wyka, [w:] K.W. Baran, Kodeks pracy. Komentarz, Warszawa 2018, s. 1211.

24 Zob. tekst jedn. Dz.U. z 2019 r. poz. 1175. Służba medycyny pracy jest właściwa do realizowania zadań z zakresu sprawowania profilaktycznej opieki zdrowotnej nad pracującymi, w szczególności przez monitorowanie stanu zdrowia osób pracujących zaliczanych do grup szczególnego ryzyka, a zwłaszcza osób wykonujących pracę w warunkach przekroczenia normatywów higienicznych, młodocianych, niepełnosprawnych oraz kobiet w wieku rozrodczym i ciężarnych. 
przypadku, zgodnie z art. 28 pkt 2 i 3 u.r.z.s.n., obiekty i pomieszczenia zakładu pracy chronionej poza tym, że odpowiadają przepisom i zasadom bezpieczeństwa i higieny pracy, dodatkowo mają uwzględniać potrzeby osób niepełnosprawnych w zakresie przystosowania stanowisk pracy, pomieszczeń higienicznosanitarnych i ciągów komunikacyjnych oraz spełniać wymagania dostępności do nich, a ponadto zapewniona musi być doraźna i specjalistyczna opieka medyczna, poradnictwo i usługi rehabilitacyjne (takie same warunki muszą spełniać zakłady aktywności zawodowej) ${ }^{25}$. Jeśli chodzi o drugi przypadek, to jak wynika $\mathrm{z}$ art. 4 ust. 5 pkt 2 u.r.z.s.n., możliwe jest zatrudnianie osób niepełnosprawnych o znacznym i umiarkowanym stopniu niepełnosprawności u pracodawcy niezapewniającego warunków pracy chronionej w razie przystosowania przez pracodawcę stanowiska pracy do potrzeb osoby niepełnosprawnej. Powodem, dla którego ustawodawca odnosi się właśnie do tych dwóch stopni niepełnosprawności, jest fakt, iż zgodnie z opisem stopni niepełnosprawności w art. 4 ust. 1 i 2 u.r.z.s.n. osoby te wykazują się zdolnością do pracy jedynie w warunkach pracy chronionej. Definicja przystosowanego stanowiska pracy osoby niepełnosprawnej została zawarta w art. 2 pkt 8 u.r.z.s.n., zgodnie z którym jest to stanowisko pracy oprzyrządowane i dostosowane odpowiednio do potrzeb wynikających $\mathrm{z}$ rodzaju i stopnia niepełnosprawności. Przystosowanie stanowiska pracy do potrzeb osoby niepełnosprawnej ma na celu przywrócenie zdolności do pracy, umożliwienie świadczenia konkretnej pracy na równi $\mathrm{z}$ osobami o nienaruszonej sprawności organizmu ${ }^{26}$. Jest to proces bardzo zindywidualizowany, ponieważ to samo schorzenie może w różnym stopniu ograniczać zdolność do pracy - trudno w tym zakresie o uniwersalizm rozwiązań ${ }^{27}$.

Szczególne rozwiązania odnoszące się do zapewniania bezpiecznych i higienicznych warunków pracy osobom niepełnosprawnym można także znaleźć w bardziej ogólnych regulacjach prawnych, niższego rzędu. Warto przywołać w tym zakresie rozporządzenie Ministra Pracy i Polityki Socjalnej z dnia 26 września 1997 r. w sprawie ogólnych przepisów bezpieczeństwa i higieny pracy ${ }^{28}$. Rozporządzenie określa ogólnie obowiązujące przepisy bezpieczeństwa i higieny pracy w zakładach pracy, w szczególności dotyczące obiektów budowalnych, pomieszczeń pracy i terenu zakładów pracy, procesów pracy, pomieszczeń i urządzeń higieniczno-sanitarnych.

$\mathrm{W} \S 48^{29}$ na pracodawców zatrudniających osoby niepełnosprawne został nałożony obowiązek zapewnienia dostosowania stanowisk pracy oraz dojść do nich - do

25

Por. art. 29 ust. 1 pkt 2 u.r.z.s.n.

M. Paluszkiewicz, [w:] Ustawa..., s. 92 i n.

D. Gabler, A. Hadław, M. Garczyński, Przystosowanie stanowiska pracy osoby niepełnosprawnej, Warszawa 2010, s. 3.

Zob. tekst jedn. Dz.U. z 2003 r. Nr 169, poz.1650.

Warto zwrócić uwagę, że w doktrynie podkreśla się, iż § 48 w sprawie ogólnych przepisów bezpieczeństwa i higieny pracy niczego nie wnosi z uwagi na to, że obciążające pracodawcę obowiązki związane z zatrudnianiem osób niepełnosprawnych mają podstawę ustawową. Zgodnie z art. 23a u.r.z.s.n. pracodawca jest obo- 
potrzeb i możliwości tych pracowników, wynikających ze zmniejszonej sprawności. Obowiązek ten oznacza zarówno konieczność odpowiedniego dostosowania drogi pracowników niepełnosprawnych do stanowiska pracy, jak i samego stanowiska ${ }^{30}$.

Ponadto, jak wynika $\mathrm{z} \$ 5$ załącznika nr 3 do rozporządzenia w sprawie ogólnych przepisów bezpieczeństwa i higieny pracy, pracodawca zatrudniający pracowników niepełnosprawnych powinien zapewnić dostosowanie urządzeń higieniczno-sanitarnych oraz dojść do nich do potrzeb i możliwości tych pracowników wynikających ze zmniejszonej sprawności, zgodnie z przepisami techniczno-budowalnymi. W szczególności chodzi o rozporządzenie Ministra Infrastruktury z dnia 12 kwietnia 2002 r. w sprawie warunków technicznych, jakim powinny odpowiadać budynki i ich usytuowanie ${ }^{31}$.

Z obowiązkiem zapewnienia pracownikom niepełnosprawnym odpowiedniego stanowiska pracy wiąże się także art. 14 u.r.z.s.n. Ustawodawca szczególną ochroną objął osoby, które w wyniku wypadku przy pracy lub choroby zawodowej utraciły zdolność do pracy na dotychczasowym stanowisku i zostały uznane za osobę niepełnosprawną, nakładając na pracodawcę obowiązek wydzielenia lub zorganizowania odpowiedniego stanowiska pracy z podstawowym zapleczem socjalnym dla tych osób. Obowiązek nałożony na pracodawcę ma charakter bezwzględny. Pracodawca zobowiązany jest dostosować stanowiska pracy oraz dojścia do nich do potrzeb i możliwości pracowników niepełnosprawnych, wynikających z ich zmniejszonej sprawności, co może polegać na przystosowaniu istniejącego stanowiska do potrzeb osób niepełnosprawnych bądź zorganizowaniu nowego, odpowiedniego ${ }^{32}$. W art. 23 u.r.z.s.n. przewidziana została sankcja dla pracodawców, którzy nie realizują ciążącego na nich obowiązku, o którym mowa powyżej. Jeżeli pracodawca nie wydzieli lub nie zorganizuje w przepisanym terminie stanowiska pracy, obowiązany jest dokonać w dniu rozwiązania stosunku pracy $\mathrm{z}$ tą osobą wpłaty na Fundusz w wysokości piętnastokrotnego przeciętnego wynagrodzenia za pracownika.

Ważną rolę w prawidłowej organizacji warunków pracy - w tym także bezpiecznych i higienicznych warunków pracy dla osób niepełnosprawnych - odgrywają niezbędne racjonalne usprawnienia, o których mowa w art. 23a u.r.z.s.n. Zgodnie z przywołaną regulacją pracodawca jest obowiązany zapewnić niezbędne racjonalne usprawnienia dla osoby niepełnosprawnej pozostającej z nim w stosun-

wiązany zapewnić niezbędne racjonalne usprawnienia dla osoby niepełnosprawnej (o czym będzie jeszcze szerzej w dalszej części opracowania). Takie stanowisko prezentuje D. Dörre-Kolasa, [w:] Akty wykonawcze prawa pracy. Komentarz, red. K. W. Baran, Warszawa 2016, s. 631.

30 J. Stępniak, Obowiązki pracodawcy zatrudniającego pracownika niepełnosprawnego. Komentarz praktyczny, Lex/el.

31 Zob. tekst jedn. Dz.U. z 2019 r. poz. 1065.

32 E. Staszewska, [w:] Ustawa o rehabilitacji zawodowej i społecznej oraz zatrudnianiu osób niepełnosprawnych. Komentarz, red. M. Włodarczyk, Warszawa 2015, s. 239 i n. 
ku pracy, uczestniczącej w procesie rekrutacji lub odbywającej szkolenie, staż, przygotowanie zawodowe albo praktyki zawodowe lub absolwenckie. Należy zwrócić uwagę, iż ustawodawca rozszerza zakres podmiotowy tego przepisu także na osoby, które nie pozostają $\mathrm{z}$ nim w stosunku pracy ${ }^{33}$. Niezbędne racjonalne usprawnienia polegają na przeprowadzeniu koniecznych w konkretnej sytuacji zmian lub dostosowań do szczególnych, zgłoszonych pracodawcy potrzeb wynikających z niepełnosprawności danej osoby, o ile przeprowadzenie takich zmian lub dostosowań nie skutkowałoby nałożeniem na pracodawcę nieproporcjonalnie wysokich obciążeń. Są to zindywidualizowane środki i z tego względu nie jest celowe tworzenie nawet przykładowych usprawnień w przepisach prawa ${ }^{34}$. Podstawowym wyznacznikiem rodzaju tych usprawnień będą potrzeby osoby niepełnosprawnej i to pracodawca, biorąc pod uwagę rodzaj wykonywanej pracy oraz sposób jej organizacji, decyduje, na czym będą one polegać. Racjonalne usprawnienia mogą polegać na przystosowaniu pomieszczenia (likwidacja barier architektonicznych), odpowiednim wyposażeniu stanowiska pracy czy też przeniesieniu stanowiska pracy na przykład z piętra na parter ${ }^{35}$. Sąd Najwyższy w wyroku z 7 grudnia $2017 \mathrm{r}^{36}$ stwierdził, że racjonalnie usprawnienie polega na podjęciu działań umożliwiających niepełnosprawnemu pracownikowi dalsze zajmowanie dotychczasowego stanowiska, a nie na eliminacji z zakresu czynności obowiązków podstawowych dla stanowiska zajmowanego przez takiego pracownika.

Zgodnie $\mathrm{z}$ tym, co wynika $\mathrm{z}$ art. 23a u.r.z.s.n., usprawnienia mają być racjonalne, a zatem uwzględniające interesy obu stron - zarówno osoby niepełnosprawnej, jak i pracodawcy z punktu widzenia jego interesu ekonomicznego ${ }^{37}$. Przeprowadzenie koniecznych zmian i dostosowań nie może skutkować nałożeniem na pracodawcę nieproporcjonalnie wysokich obciążeń. $Z$ art. 23a ust. 2 u.r.z.n.s. dodatkowo wynika, iż obciążenia nie są nieproporcjonalne, jeżeli są w wystarczającym stopniu rekompensowane ze środków publicznych. Nieuzasadniona powyższymi względami odmowa dokonania racjonalnych usprawnień zgodnie $\mathrm{z}$ art. 23a ust. 3 u.r.z.s.n. stanowi naruszenie zasady równego traktowania $\mathrm{w}$ rozumieniu przepisów art. $13^{3 \mathrm{a}}$ $\S 2-5 \mathrm{kp}$.

Należy zwrócić uwagę, że ustawodawca w związku z koniecznością zapewniania niepełnosprawnym szczególnych warunków świadczenia pracy próbuje zrekompensować pracodawcom określone koszty związane $\mathrm{z}$ dostosowywaniem

Por. M. Kuba, E. Staszewska, $P$
Prawa Pracy" 2019, nr 3, s. 24.

34 M. Paluszkiewicz, Wolność pracy osób..., s. 319.

35 M. Brząkowski, Zatrudnianie niepełnosprawnych, Warszawa 2014, s. 180.

36 Wyrok SN z dnia 7 grudnia 2017 r., I PK 334/16, OSNP 2018/9/119.

37 M. Paluszkiewicz, Obowiązek pracodawcy zapewniania osobie niepełnosprawnej niezbędnych racjonalnych usprawnień, [w:] Współczesne problemy prawa emerytalnego, red. T. Bińczycka-Majewska, M. Włodarczyk, Warszawa 2015, s. 323 i n. 
warunków pracy dla tych osób, co ma niewątpliwie stanowić dla pracodawców zachętę do zatrudniania osób z niepełnosprawnościami oraz zapobiegać wykluczeniu ich z rynku pracy. W kontekście omawianych regulacji z zakresu zapewniania bezpiecznych i higienicznych warunków pracy osobom niepełnosprawnym istotne znaczenie ma art. 26 u.r.z.s.n., przewidujący zwrot pewnych dodatkowych kosztów, jakie pracodawca ponosi w przedmiotowym zakresie. Chodzi m.in. o zwrot kosztów adaptacji pomieszczeń zakładu pracy do potrzeb osób niepełnosprawnych, w szczególności poniesionych w związku z przystosowaniem tworzonych lub istniejących stanowisk pracy dla tych osób, stosownie do potrzeb wynikających z ich niepełnosprawności (art. 26 ust. 1 pkt 1 u.r.z.s.n.), adaptacji lub nabycia urządzeń ułatwiających osobie niepełnosprawnej wykonywanie pracy lub funkcjonowanie w zakładzie pracy (art. 26 ust. 1 pkt 1b u.r.z.s.n.), zakupu i autoryzacji oprogramowania na użytek pracowników niepełnosprawnych oraz urządzeń technologii wspomagających lub przystosowanych do potrzeb wynikających $z$ ich niepełnosprawności (art. 26 ust. 1 pkt 1c u.r.z.s.n) ${ }^{38}$. Zwrot kosztów nie może przekraczać dwudziestokrotnego przeciętnego wynagrodzenia za każde przystosowane stanowisko pracy i dotyczy wyłącznie dodatkowych kosztów pracodawcy wynikających z zatrudnienia osób niepełnosprawnych ${ }^{39}$. Ustawodawca wprowadza także określone wymagania, jeśli o chodzi o okres zatrudniania osób niepełnosprawnych oraz ich status (por. art. 26 ust. 2 u.r.z.s.n.) ${ }^{40}$.

W ramach szczególnej ochrony pracy osób niepełnosprawnych ważne miejsce zajmują uprawnienia pracownicze, jakie zostały im zagwarantowane w zakresie czasu pracy oraz urlopów wypoczynkowych. Jak zaznaczono na wstępie, w szerszym rozumieniu ochrony pracy również i te instytucje zaliczają się do jej zakresu przedmiotowego $^{41}$. Nie można mieć wątpliwości, że wraz z przepisami regulującymi zapewnienie bezpiecznych i higienicznych warunków pracy przeciwdziałają ujemnemu wpływowi pracy na zdrowie ${ }^{42}$, co w przypadku osób niepełnosprawnych nabiera znaczenia. W przypadku wspomnianych uprawnień ustawodawca zdecydował się jednak na dyferencjację rozwiązań. Część z nich przysługuje wszystkim osobom niepełnosprawnym (bez względu na stopień niepełnosprawności), a nie-

Szeroko na ten temat E. Staszewska, [w:] Ustawa o rehabilitacji..., s. 508 i n.

Szczegóły dotyczące zasad i trybu dokonywania zwrotu kosztów adaptacyjnych zostały uregulowane w rozporządzeniu Ministra Pracy i Polityki Społecznej z dnia 23 grudnia 2014 r. w sprawie zwrotu dodatkowych kosztów związanych z zatrudnianiem pracowników niepełnosprawnych (Dz.U. z 2014 r. poz. 1987).

Zwrot kosztów dotyczy osób niepełnosprawnych bezrobotnych lub poszukujących pracy niepozostających w zatrudnieniu, ewentualnie pozostających w zatrudnieniu u pracodawcy występującego o zwrot kosztów, z wyjątkiem przypadków, gdy przyczyną powstania niepełnosprawności w okresie zatrudnienia u tego pracodawcy było zawinione przez pracodawcę lub przez pracownika naruszenie przepisów, w tym przepisów prawa pracy.

T. Wyka, Ochrona pracy w dorobku naukowym Profesora Wacława Szuberta, [w:] Prawo ochrony pracy współczesność i perspektywy rozwoju, red. T. Wyka, M.A. Mielczarek, Warszawa 2017, s. 40.

W. Szubert, Ochrona pracy. Studium społeczno-prawne, Warszawa 1966, s. 33. 
które będą przysługiwały wyłącznie pracownikom niepełnosprawnym o znacznym lub umiarkowanym stopniu niepełnosprawności. Jest to wynikiem tego, iż osoby niepełnosprawne stanowią swoistą grupę pracowników, podzieloną wewnętrznie według stopnia niepełnosprawności ${ }^{43}$.

W zakresie czasu pracy na szczególne regulacje odnoszące się do osób niepełnosprawnych składają się obniżone normy czasu pracy, ograniczenia pracy w godzinach nadliczbowych i porze nocnej, dodatkowe przerwy w pracy.

Jak wynika $\mathrm{z}$ art. 15 ust. 1 u.r.z.s.n., zasadą odnoszącą się do wszystkich osób niepełnosprawnych, niezależnie od stopnia niepełnosprawności (z wyjątkami, o których będzie mowa dalej), jest 8-godzinna norma dobowa i 40-godzinna norma tygodniowa. Pracodawca ma obowiązek jednoczesnego zachowania obu norm dobowej i tygodniowej - w odniesieniu do pracowników niepełnosprawnych. Normy te należy traktować jako maksymalne i sztywne. Wynika to $\mathrm{z}$ faktu, że art. 15 u.r.z.s. odnosi się do maksymalnych wartości norm czasu pracy, a nie do norm przeciętnych - jak ma to miejsce w Kodeksie pracy ${ }^{44}$. Jednocześnie art. 15 ust. 2 u.r.z.s.n. wprowadza obowiązek stosowania w pewnych przypadkach krótszych niż omówione powyżej norm, a mianowicie 7-godzinnej normy dobowej i 35-godzinnej normy tygodniowej. Pracodawca ma obowiązek stosować skrócone normy, w razie gdy pracownik niepełnosprawny posiada stosowne orzeczenie potwierdzające jego niepełnosprawność w znacznym lub umiarkowanym stopniu.

Przepisy o skróconej normie czasu pracy mają na celu ochronę zdrowia pracowników z niepełnosprawnościami, zwiększenie szans na zatrudnienie na rynku pracy - mimo niepełnosprawności - oraz umożliwienie rehabilitacji poprzez pracę. Normy czasu pracy osoby zaliczonej do znacznego lub umiarkowanego stopnia niepełnosprawności w ustawie rehabilitacyjnej wyznaczają „pełny” wymiar dla takiego zatrudnionego. Skrócenie czasu pracy następuje na okres występowania okoliczności uzasadniających zastosowanie niższych norm jego wymiaru. Jeśli zatrudniony utraci status osoby niepełnosprawnej w stopniu znacznym lub umiarkowanym, będzie to uzasadniało powrót do norm czasu pracy przewidzianych w art. 15 ust. 1 u.r.z.s.n. ${ }^{45}$

$\mathrm{Z}$ art. 15 ust. 3 u.r.z.s.n. wynika kolejne uprawnienie o charakterze ochronnym - osoby niepełnosprawne nie mogą być zatrudniane w porze nocnej i w godzinach

\footnotetext{
43 Por. Uchwała SN z dnia 18 kwietnia 2000 r., III ZP 6/00, OSNP 200/20/74.

$44 \quad$ Z art. $129 \mathrm{kp}$. $\S 1$ wynika, że czas pracy nie może przekraczać 8 godzin na dobę i przeciętnie 40 godzin w przeciętnie 5-dniowym tygodniu pracy w przyjętym okresie rozliczeniowym nieprzekraczającym 4 miesięcy, z zastrzeżeniem art. 135-138, 143 i $144 \mathrm{kp}$.

45 K. Roszewska, Glosa do wyroku Sądu Najwyższego z dnia 3 sierpnia 2016 r., I PK 168/15, OSP 2018/2/19, Lex/el.
} 
Ochrona pracy osób niepełnosprawnych

nadliczbowych. Ochrona w tym zakresie dotyczy wszystkich niepełnosprawnych, którzy przedstawią pracodawcy orzeczenie potwierdzające niepełnosprawność.

Pracowników niepełnosprawnych nie wolno także zatrudniać w godzinach nadliczbowych, których definicję zawiera art. $151 \mathrm{kp}$. - jest to praca wykonywana ponad obowiązujące pracownika normy czasu pracy, a także ponad przedłużony dobowy wymiar czasu pracy, wynikający z obowiązującego pracownika systemu i rozkładu czasu pracy. Mając na uwadze różne normy czasu pracy odnoszące się do konkretnego pracownika niepełnosprawnego, należy stwierdzić, że pracą nadliczbową będzie praca ponad normy czasu pracy, mające zastosowanie w odniesieniu do konkretnego pracownika ${ }^{46}$. W razie gdyby pracodawca wbrew zakazowi zlecił wykonywanie pracownikowi niepełnosprawnemu pracy w godzinach nadliczbowych bądź w porze nocnej, należy przyjąć, że nie pozbawia to pracownika stosownych dodatków za pracę w godzinach nadliczbowych czy porze nocnej. Sąd Najwyższy w wyroku z dnia 6 lipca 2005 r. ${ }^{47}$ stwierdził, że ustalenie w umowie o pracę zawartej z pracownikiem niepełnosprawnym w stopniu umiarkowanym 8-godzinnego dnia pracy zamiast zgodnego z prawem 7-godzinnego oznacza, że za każdą przepracowaną ósmą godzinę ma on prawo do wynagrodzenia w wysokości 1/7 dziennego wynagrodzenia wynikającego z umowy i do dodatku za pracę w godzinach nadliczbowych ${ }^{48}$. W innym wyroku ${ }^{49}$ Sąd Najwyższy ustalił, iż za ósmą godzinę pracy w ciągu doby niepełnosprawnemu pracownikowi należy się rekompensata $\mathrm{z}$ tytułu wykonywania obowiązków w nadgodzinach. Pracodawca nie może twierdzić, że nieprzestrzeganie ustawowego limitu czasu pracy takich osób może być dla nich korzystne i ma przeciwdziałać dyskryminacji.

Jednocześnie w art. 16 u.r.z.s.n. ustawodawca wobec pewnych kategorii osób niepełnosprawnych wyłączył stosowanie omówionych powyżej szczególnych regulacji dotyczących czasu pracy określonych w art. 15 u.r.z.s.n., z których wynika, że czas pracy osoby niepełnosprawnej nie może przekraczać 8 godzin na dobę i 40 godzin tygodniowo, a czas pracy osoby niepełnosprawnej zaliczonej do znacznego lub umiarkowanego stopnia niepełnosprawności nie może przekraczać 7 godzin na dobę i 35 godzin tygodniowo, oraz że osoba niepełnosprawna nie może być zatrudniona w porze nocnej i w godzinach nadliczbowych. Wyłączenie stosowania wskazanych zasad dotyczy osób niepełnosprawnych zatrudnionych przy pilnowaniu oraz osób niepełnosprawnych, na wniosek których lekarz przeprowadzający

\footnotetext{
46 L. Klimkiewicz, Czas pracy osób niepełnosprawnych, cz. 2, „Służba Pracownicza” 2011, nr 1 s. 18.

47 Wyroku SN z dnia 6 lipca 2005 r., III PK 51/05, OSNP 2006/5-6/85.

48 Por. K. Gonera, Jak obliczać stawkę za godziny nadliczbowe niepełnosprawnego, „Służba Pracownicza” 2007, nr 3, s. XXI; L. Grzonka, Zatrudnianie osób niepełnosprawnych, Warszawa 2010, s. 19. Wyrok SN z dnia 3 sierpnia 2016 r., I PK 168/15, LEX nr 2087686.
} 
badania profilaktyczne pracowników lub - w razie jego braku - lekarz sprawujący opiekę nad tą osobą wyrazi na to zgodę ${ }^{50}$.

Osoby niepełnosprawne zatrudnione przy pilnowaniu poprzez wyłączenie stosowania art. 15 u.r.z.s.n. objęte są zwykłą regulacją Kodeksu pracy, bez konieczności uzyskania zgody lekarza. Można zatem stosować do nich ogólne zasady dotyczące czasu pracy, tak jak w przypadku pracowników pełnosprawnych. Wydaje się, że przyjęte rozwiązanie należy ocenić krytycznie, biorąc pod uwagę, że w ten sposób osoby niepełnosprawne zaliczone do znacznego stopnia niepełnosprawności będą traktowane jak pracownicy pełnosprawni, bez możliwości skrócenia norm czasu pracy, które gwarantuje art. 15 u.r.z.s.n. Ogólne normy czasu pracy wynikające z Kodeksu pracy stosuje się do osób niepełnosprawnych od momentu podjęcia przez nie zatrudnienia przy pilnowaniu.

Druga grupa osób niepełnosprawnych, do których nie stosuje się art. 15 u.r.z.s.n., to osoby niepełnosprawne, które na swój wniosek uzyskały na to zgodę od lekarza przeprowadzającego badania profilaktyczne lub - w razie jego braku - od lekarza sprawującego opiekę nad tą osobą. Warunkiem koniecznym jest w tym przypadku wniosek osoby zainteresowanej, która w dniu składania wniosku musi pozostawać w zatrudnieniu. A zatem nie można wystąpić o taką zgodę jeszcze przed podjęciem zatrudnienia. Takie rozwiązanie należy z kolei ocenić pozytywnie. Zapobiega to sytuacji, w której pracodawca warunkuje zatrudnienie osoby niepełnosprawnej od uzyskania zgody lekarza, obawiając się konieczności stosowania skróconych norm czasu pracy. Momentem wyłączenia stosowania art. 15 u.r.z.s. do tej grupy jest doręczenie pracodawcy zgody lekarza. Koszty ewentualnych badań, na które będzie kierował lekarz celem ustalenia dopuszczalności stosowania do osoby niepełnosprawnej ogólnych norm czasu pracy, obciążają pracodawcę.

Kolejnym przywilejem pracowników niepełnosprawnych o charakterze ochronnym w zakresie czasu pracy jest dodatkowa przerwa w pracy. Jak wynika $\mathrm{z}$ art. 17 u.r.z.s.n., osobom niepełnosprawnym, bez względu na stopień niepełnosprawności, przysługuje wliczana do czasu pracy dodatkowa przerwa $\mathrm{w}$ pracy na gimnastykę usprawniającą lub wypoczynek w wymiarze 15 minut. Przerwa jest niezależna od innych przerw wynikających zarówno z Kodeksu pracy, jak i innych aktów prawnych. Szczególnie jest niezależna od przerwy zagwarantowanej w art. 134 kp., zgodnie z którym, jeżeli dobowy wymiar czasu pracy pracownika wynosi co najmniej 6 godzin, pracownik ma prawo do wliczanej do czasu pracy przerwy trwającej co najmniej 15 minut. Prawo do skorzystania z dodatkowej przerwy nie wymaga od osób niepełnosprawnych spełnienia jakiejkolwiek dodat-

50 E. Staszewska, Szczególne uprawnienia pracownicze osób niepełnosprawnych, [w:] Prawo a niepełnosprawność. Wybrane aspekty, red. M. Bosak, Warszawa 2015, s. 39 
Ochrona pracy osób niepełnosprawnych

kowej przesłanki, jak ma to miejsce w przypadku niektórych przywilejów ${ }^{51}$. Prawo do 15-minutowej przerwy jest niezależne od wymiaru czasu pracy osoby niepełnosprawnej, a także od tego, czy daną osobę niepełnosprawną obowiązuje norma podstawowa 8-godzinna czy skrócona - 7-godzinna.

Konieczność uwzględniania zróżnicowanych potrzeb wynikających z niepełnosprawności stanowi ratio legis dla dodatkowego urlopu wypoczynkowego oraz celowych zwolnień od pracy, dzięki którym osoby z niepełnosprawnością w stopniu znacznym lub umiarkowanym mogą korzystać z usług rehabilitacyjnych, medycznych, a także z zaopatrzenia ortopedycznego ${ }^{52}$.

Jeśli chodzi o szczególną regulację urlopową, to jak wynika z art. 19 u.r.z.s.n., pracownikom niepełnosprawnym posiadającym orzeczenie o znacznym lub umiarkowanym stopniu niepełnosprawności przysługuje prawo do dodatkowego urlopu wypoczynkowego w wymiarze $10 \mathrm{dni}$ roboczych w roku kalendarzowym. Prawo do dodatkowego urlopu przysługuje wyłącznie osobom niepełnosprawnym legitymującym się wskazanymi wyżej stopniami niepełnosprawności, a zatem osoby niepełnosprawne zaliczone do lekkiego stopnia niepełnosprawności prawa do dodatkowego urlopu nie posiadają. Posiadanie przez pracowników niepełnosprawnych orzeczenia o znacznym lub umiarkowanym stopniu niepełnosprawności zwiększa wymiar urlopu wypoczynkowego z 20 do 30 dni albo z 26 do 36 dni - w zależności od posiadanego stażu warunkującego wymiar urlopu. Wymiar urlopu dla pracownika zatrudnionego w niepełnym wymiarze czasu pracy, uprawnionego do dodatkowego urlopu wypoczynkowego, ustala się proporcjonalnie do wymiaru czasu pracy tego pracownika (art. $154 \$ 2 \mathrm{kp}$.). Prawo do pierwszego dodatkowego urlopu wypoczynkowego osoba niepełnosprawna nabywa po przepracowaniu 1 roku po dniu zaliczenia jej do umiarkowanego lub znacznego stopnia niepełnosprawności. W art. 19 ust. 2 u.r.z.s.n. zostały wskazane przypadki, w których dodatkowy urlop wypoczynkowy nie przysługuje. Chodzi o osoby niepełnosprawne zaliczone do znacznego lub umiarkowanego stopnia niepełnosprawności uprawnione do urlopu wypoczynkowego w wymiarze przekraczającym 26 dni roboczych lub uprawnione do urlopu dodatkowego na podstawie odrębnych przepisów. Jednak, gdy wymiar urlopu wypoczynkowego przekraczającego 26 dni bądź urlopu dodatkowego na podstawie odrębnych przepisów byłby niższy niż 10 dni roboczych, wówczas zamiast tego urlopu będzie przysługiwał urlop dodatkowy w wymiarze $10 \mathrm{dni}$, wynikający z art. 19 u.r.z.s.

W przypadku osób niepełnosprawnych szczególnego znaczenia nabiera dbałość o dobrą kondycję psychofizyczną, umożliwiającą wykonywanie pracy, co z kolei wiąże się z koniecznością wzmożonej aktywności na tym polu. Z tego względu

51 J. Suzdorf, Przerwy w pracy a przerywany czas pracy, „Służba Pracownicza” 2000, nr 44(1).
52 M. Paluszkiewicz, Wolność pracy osób..., s. 316. 
w art. 20 u.r.z.s.n. przewidziane zostały określone zwolnienia od pracy z zachowaniem prawa do wynagrodzenia. Przywilej ten został skierowany wyłącznie do osób niepełnosprawnych legitymujących się orzeczeniem o znacznym lub umiarkowanym stopniu niepełnosprawności. Zwolnienia przysługują osobom niepełnoprawnych w dwóch sytuacjach. Po pierwsze, osoba niepełnosprawna ma prawo do zwolnienia od pracy w wymiarze do 21 dni roboczych w celu uczestniczenia w turnusie rehabilitacyjnym nie częściej niż raz w roku. Bez wątpienia uczestnictwo w turnusach rehabilitacyjnych jest formą aktywności wspomagającej proces rehabilitacji zawodowej i społecznej. Zgodnie $\mathrm{z}$ art. 10c u.r.z.s. turnus rehabilitacyjny oznacza zorganizowaną formę aktywnej rehabilitacji połączonej z elementami wypoczynku, której celem jest ogólna poprawa psychofizycznej sprawności oraz rozwijanie umiejętności społecznych uczestników, m.in. przez nawiązywanie i rozwijanie kontaktów społecznych, realizację i rozwijanie zainteresowań, a także przez udział w innych zajęciach przewidzianych programem turnusu. Osoby niepełnosprawne są kierowane do uczestnictwa w turnusach rehabilitacyjnych na wniosek lekarza, pod którego opieką się znajdują (art. 10f ust. 1 pkt 2 u.r.z.s.n.). Wymiar przedmiotowego zwolnienia od pracy wynosi maksymalnie $21 \mathrm{dni}$. Ustawodawca zastrzegł jednak w art. 20 ust. 3 u.r.z.s.n., że łączny wymiar urlopu dodatkowego osób niepełnosprawnych (10 dni, o których mowa w art. 19 u.r.z.s.n.) i zwolnienia od pracy w celu wzięcia udziału w turnusie nie może przekroczyć 21 dni roboczych w roku kalendarzowym. Drugim rodzajem zwolnienia jest zwolnienie od pracy w celu wykonania badań specjalistycznych, zabiegów leczniczych lub usprawniających, a także w celu uzyskania zaopatrzenia ortopedycznego lub jego naprawy, jeżeli czynności te nie mogą być wykonane poza godzinami pracy. W przypadku tego zwolnienia muszą być łącznie spełnione dwie przesłanki. Po pierwsze, zwolnienie podyktowane jest koniecznością wykonania badań specjalistycznych, zabiegów leczniczych lub usprawniających, a także w celu uzyskania zaopatrzenia ortopedycznego lub jego naprawy. Drugą przesłanką jest natomiast brak możliwości wykonania wskazanych czynności poza godzinami pracy. Zwolnienie od pracy we wskazanych powyżej okolicznościach obejmuje czas ich wykonania wraz z niezbędnym czasem na dojazd i powrót, co oznacza, że może obejmować kilka godzin lub nawet cały dzień, jeśli na przykład placówka znajduje się poza miejscowością, w której świadczona jest praca. Co istotne, ustawodawca nie wskazał rocznego limitu, jak ma to miejsce w przypadku zwolnienia w celu wzięcia udziału w turnusie rehabilitacyjnym. Oznacza to, że osoba niepełnosprawna może wielokrotnie w ciągu roku korzystać z tego rodzaju zwolnieńn ${ }^{53}$, które nie będą wliczane do limitu 21 dni roboczych, udzielanych w związku z uczestniczeniem w turnusie rehabilitacyjnym. 
Analiza powyższych obowiązków pracodawcy względem pracowników niepełnosprawnych składa się na szczególną, wzmożoną ochronę pracy tej grupy. Powstaje w tym miejscu wątpliwość, w jakim momencie i na jakiej podstawie pracodawca dowiaduje się, że zatrudnia osobę niepełnosprawną, której pracę jest winien objąć szczególną ochroną, realizując tym samym wszystkie przysługujące jej uprawnienia? Czy osoba niepełnosprawna ma obowiązek ujawniania swojej niepełnosprawności, a pracodawca w związku z tym ma prawo do pozyskiwania informacji o niej?

Tak jak zostało już zaznaczone na początku opracowania, niepełnosprawność musi zostać potwierdzona stosownym orzeczeniem. Co więcej, niektóre z uprawnień przysługujących pracownikom niepełnosprawnym zostały uzależnione od legitymowania się określonym stopniem niepełnosprawności. Prawo pracodawcy do pozyskiwania informacji o niepełnosprawności pracownika (osoby ubiegającej się o nawiązanie stosunku pracy) to zagadnienie złożone i wielowymiarowe ${ }^{54}$. Należy je rozpatrywać $w$ oparciu o przepisy z zakresu ochrony danych osobowych, przepisy Kodeksu pracy odnoszące się do pozyskiwania danych od kandydatów na pracowników i pracowników już zatrudnionych oraz wreszcie w oparciu o przepisy ustawy o rehabilitacji zawodowej.

Informację dotyczącą niepełnosprawności należy kwalifikować jako dane dotyczące zdrowia, które zgodnie z art. 4 pkt 15 rozporządzenia Parlamentu Europejskiego i Rady (UE) 2016/679 z dnia 27 kwietnia 2016 r. w sprawie ochrony osób fizycznych w związku z przetwarzaniem danych osobowych i w sprawie swobodnego przepływu takich danych oraz uchylenia dyrektywy 95/46/WE ${ }^{55}$ oznaczają dane osobowe o zdrowiu fizycznym lub psychicznym osoby fizycznej - w tym o korzystaniu z usług opieki zdrowotnej - ujawniające informacje o stanie jej zdrowia. Są to więc informacje o stanie zdrowia fizycznego lub psychicznego człowieka ${ }^{56}$. Dane te zostały zaliczone do szczególnej kategorii danych osobowych (tzw. danych wrażliwych), a kwestie dopuszczalności ich przetwarzania reguluje art. $9 \mathrm{RODO}^{57}$. Zgodnie $\mathrm{z}$ ust. 1 tego przepisu, choć co do zasady zabrania się przetwarzania danych dotyczących zdrowia, to jednak w ust. 2 wskazano, iż nie stosuje się tej reguły, gdy m.in. osoba, której dane dotyczą, wyraziła zgodę na przetwarzanie tych danych $\mathrm{w}$ jednym lub kilku konkretnych celach, a także gdy przetwarzanie jest niezbędne do wypełnienia obowiązków i wykonywania szczególnych praw przez administra-

\footnotetext{
54 K. Szymorek, Prawo pracodawcy do pozyskiwania informacji o niepełnosprawności pracownika oraz osoby ubiegającej się o zatrudnienie, [w:] A. Giedrewicz-Niwińska, M. Szabłowska-Juckiewicz, Zatrudnianie osób niepełnosprawnych. Regulacje prawne, Warszawa 2014, s. 219.

55 Dz.U. UE L.2016.119.1, dalej jako RODO.

56 M. Kuba, [w:] RODO. Ogólne rozporządzenie o ochronie danych. Komentarz, red. E. Bielak-Jomaa, D. Lubasz, Warszawa 2018, s. 444.

57 Szeroko na ten temat M. Kuba, [w:] RODO..., s. 445 i n.
} 
tora lub osobę, której dane dotyczą, w dziedzinie prawa pracy, zabezpieczenia społecznego i ochrony socjalnej.

W Kodeksie pracy zakres danych, których żąda pracodawca od osób ubiegających się o zatrudnienie i pracowników, został określony w art. $22^{1} \mathrm{kp}$. Co do zasady, zgodnie z art. $22^{1} \mathrm{kp} . \$ 1 \mathrm{kp}$. pracodawca żąda od osoby ubiegającej się o zatrudnienie podania danych osobowych obejmujących: imię i nazwisko, datę urodzenia, dane kontaktowe, wykształcenie, kwalifikacje zawodowe i przebieg dotychczasowego zatrudnienia. Od pracownika zaś pracodawca żąda na podstawie art. $22^{1} \mathrm{kp} . \S 3$ pkt $3 \mathrm{kp}$. podania dodatkowo innych danych osobowych, jeżeli podanie takich danych jest konieczne ze względu na korzystanie przez pracownika ze szczególnych uprawnień przewidzianych w prawie pracy.

Ponadto w art. $22^{1} \mathrm{kp}$. $\$ 4 \mathrm{kp}$. ustawodawca zastrzegt, iż pracodawca żąda od pracownika i osoby ubiegającej się o zatrudnienie innych danych osobowych, gdy jest to niezbędne do zrealizowania uprawnienia lub spełnienia obowiązku wynikającego z przepisu prawa. Udostępnienie pracodawcy danych osobowych następuje w formie oświadczenia osoby, której dane dotyczą. Pracodawca może żądać udokumentowania danych osobowych $\mathrm{w}$ zakresie niezbędnym do ich potwierdzenia (art. $22^{1} \mathrm{kp}$. $\$ 5 \mathrm{kp}$.). Wydaje się zatem, że w kontekście przedstawiania orzeczenia o niepełnosprawności pracodawca żąda jego przedłożenia w razie realizacji szczególnych uprawnień dla osób niepełnosprawnych wynikających z ustawy o rehabilitacji zawodowej i społecznej oraz zatrudnianiu osób niepełnosprawnych, co będzie spójne z regulacjami wynikającymi właśnie z ustawy o rehabilitacji. A contrario, $\mathrm{w}$ razie braku realizacji tych uprawnień (osoba niepełnosprawna nie chce ujawniać orzeczenia o niepełnosprawności i korzystać ze szczególnej ochrony) trudno co do zasady mówić o prawie do żądania orzeczenia o niepełnosprawności.

W ustawie o rehabilitacji zawodowej, a zatem kluczowym akcie odnoszącym się do zatrudniania osób niepełnosprawnych, $w$ art. $2 \mathrm{~b}$ ust. 1 u.r.z.s.n. pracodawcy zostali wyposażeni $\mathrm{w}$ prawo do przetwarzania danych osobowych - w tym danych o stanie zdrowia m.in. osób pozostających $\mathrm{z}$ nimi w stosunku pracy, uczestniczących $\mathrm{w}$ procesie rekrutacji, odbywających szkolenie, staż, przygotowanie zawodowe albo praktyki zawodowe lub absolwenckie - dla celów określonych w ustawie, zastrzegając jednocześnie $\mathrm{w}$ ust. 2, iż przedstawienie dokumentów potwierdzających dane osobowe o stanie zdrowia jest dobrowolne. Bez wątpienia jednym z celów ustawy jest zagwarantowanie realizacji wzmożonej ochrony pracy osób niepełnosprawnych, co przejawia się w omówionych w opracowaniu regulacjach dotyczących szczególnych uprawnień pracowniczych. W mojej ocenie, choć $z$ art. $2 b$ ust. 2 u.r.z.s.n. jednoznacznie wynika, że przedstawienie dokumentów potwierdzających dane osobowe o stanie zdrowia jest dobrowolne, to dla udzielenia odpowiedzi na zadane wcześniej pytanie odnośnie do prawa żądania od osób niepełno- 
sprawnych orzeczenia potwierdzającego niepełnosprawność kluczowe znaczenie mają art. 2a i 20c u.r.z.s.n. Otóż zgodnie z art. 20c u.r.z.s.n. osobie niepełnosprawnej przysługują uprawnienia pracownicze określone w rozdziale 4 „Uprawnienia osób niepełnosprawnych" odpowiednio od dnia, od którego osoba niepełnosprawna została wliczona do stanu zatrudnienia osób niepełnosprawnych na podstawie art. 2a u.r.z.s.n. Osobę niepełnosprawną na podstawie tego przepisu wlicza się do stanu zatrudnienia osób niepełnosprawnych, począwszy od dnia przedstawienia pracodawcy orzeczenia potwierdzającego niepełnosprawność. Do uprawnień pracowniczych przysługujących niepełnosprawnym przewidzianych w przywołanym rozdziale należą składające się na wzmożoną ochronę pracy uprawnienia w zakresie czasu pracy (art. 15-17 u.r.z.s.n.), urlopów wypoczynkowych (art. 19-20 u.r.z.s.n.), wydzielenia lub zorganizowania odpowiedniego stanowiska pracy (art. 14 u.r.z.s.n.). A zatem korelatywnie związane $\mathrm{z}$ tymi uprawnieniami obowiązki pracodawcy aktualizują się, począwszy od dnia przedstawienia pracodawcy orzeczenia potwierdzającego niepełnosprawność. Zdaniem Magdaleny Paluszkiewicz w konsekwencji obowiązki te mają charakter reakcyjny, co oznacza, że pracodawca będzie je realizować po ujawnieniu przez pracownika orzeczenia o niepełnosprawności ${ }^{58}$.

Podobny charakter będzie miał składający się na ochronę pracy osób niepełnosprawnych wynikający $z$ art. 23a u.r.z.s.n. obowiązek pracodawcy zapewnienia niezbędnych racjonalnych usprawnień, co wynika zresztą z treści samego przepisu - niezbędne racjonalne usprawnienia polegają na przeprowadzeniu koniecznych w konkretnej sytuacji zmian lub dostosowań do szczególnych, zgłoszonych pracodawcy potrzeb wynikających z niepełnosprawności danej osoby ${ }^{59}$.

Jeśli chodzi o obowiązki z zakresu zapewnienia pracownikom niepełnosprawnym bezpiecznych i higienicznych warunków pracy, na które składają się m.in. konieczność przystosowania stanowisk pracy (art. 28 pkt 2 i 3 u.r.z.s.n., art. 4 ust. 5 pkt 2 u.r.z.s.n.), dostosowania stanowisk pracy i urządzeń higienicznosanitarnych oraz dojść do nich do potrzeb i możliwości tych pracowników wynikających ze zmniejszonej sprawności ( $\$ 48$ rozporządzenia w sprawie ogólnych przepisów bezpieczeństwa i higieny pracy), to aktualizacja tych obowiązków będzie uzależniona od zatrudnienia osoby niepełnosprawnej, czyli takiej, która przedstawi pracodawcy stosowne orzeczenie ${ }^{60}$. Z powyższego wynika, że nieujawnienie orzeczenia o niepełnosprawności powoduje, iż pracodawca nie jest zobowiązany do realizacji szczególnej ochrony pracy osób niepełnosprawnych, co nie oznacza, że jest zwolniony z powszechnego obowiązku ochrony pracy.

\footnotetext{
58 M. Paluszkiewicz, Ujawnianie orzeczenia..., s. 340.

59 Por. też wyrok WSA w Gorzowie Wielkopolskim z dnia 9 listopada 2017 r., II SA/Go 536/17, LEX nr 2399983.

60 M. Paluszkiewicz, Ujawnianie orzeczenia..., s. 341.
} 
Osoby niepełnosprawne ze względu na swoje fizyczne lub psychiczne ograniczenia nie zawsze mogą swobodnie oraz z zachowaniem pełnej równości korzystać z praw przysługujących każdemu człowiekowi. Dla urzeczywistnienia zasady równości i sprawiedliwości społecznej osoby niepełnosprawne objęte są szczególną pomocą władz publicznych, co ma zapobiegać ich społecznej ekskluzji i umożliwiać funkcjonowanie w społeczeństwie na równi z jego pozostałymi członkami. Wzmożona pomoc wobec osób niepełnosprawnych ma wielowymiarowy charakter i składa się na status osób niepełnosprawnych w polskim systemie prawa ${ }^{61}$. Nie można mieć żadnych wątpliwości co do konieczności obejmowania pracowników niepełnosprawnych regulacjami składającymi się na wzmożoną ochronę pracy osób niepełnosprawnych - biorąc pod uwagę ich szczególne właściwości psychofizyczne. Gwarancje wynikające z powszechnie obowiązujących przepisów (które również dotyczą pracowników niepełnosprawnych) nie byłyby dostateczne. Polski ustawodawca wzmożoną ochronę pracy niepełnosprawnych realizuje przede wszystkim poprzez przyznanie dodatkowych/specjalnych uprawnień pracowniczych, które zostały zagwarantowane $w$ ustawie o rehabilitacji zawodowej i społecznej oraz zatrudnianiu osób niepełnosprawnych. Pewne regulacje, odnoszące się zwłaszcza do obowiązku zapewnienia bezpiecznych i higienicznych warunków pracy, można odnaleźć w bardziej ogólnych regulacjach zawartych w Kodeksie pracy i wydanych na podstawie jego przepisów aktach wykonawczych.

Jeśli chodzi o regulacje odnoszące się do bezpiecznych i higienicznych warunków pracy omówione w niniejszym opracowaniu, to należy uznać je w zasadzie za wystarczające - pod warunkiem jednak, że osoba podejmująca zatrudnienie ujawnia swoje orzeczenie o niepełnosprawności pracodawcy, który mając tę wiedzę, może odpowiednio dostosować warunki pracy do jej potrzeb. Jeżeli jednak osoba niepełnosprawna nie przedkłada orzeczenia, pracodawca gwarantuje jej pracę na ogólnych zasadach, co może okazać się niewystarczające. A przecież na mocy art. $207 \mathrm{kp}$. to pracodawca ponosi odpowiedzialność za stan bhp w zakładzie pracy i to on jest zobowiązanych chronić zdrowie i życie pracowników przez zapewnienie bhp. Wydaje się, że kluczowe znaczenie w tym zakresie winna spełniać profilaktyczna ochrona zdrowia. Zgodnie z art. $229 \$ 4 \mathrm{kp}$. pracodawca nie może dopuścić do pracy pracownika bez aktualnego orzeczenia lekarskiego stwierdzającego brak przeciwwskazań do pracy na określonym stanowisku w warunkach pracy opisanych w skierowaniu na badania lekarskie. W ten sposób lekarz ocenia zdolność danej osoby do wykonywania pracy.

Składające się na wzmożoną ochronę pracy niepełnosprawnych przepisy dotyczące czasu pracy czy urlopów wypoczynkowych są silnie zakorzenione w polskim 
ustawodawstwie pracy. Czas pracy osób niepełnosprawnych uregulowany został w odmienny sposób w porównaniu do pracowników pełnosprawnych, co ma źródło już w powojennych regulacjach prawnych ${ }^{62}$. Zmiany w tym zakresie nie spotkały się w przeszłości z aprobatą ${ }^{63}$, czego dowodem jest wyrok Trybunału Konstytucyjnego z dnia 13 czerwca 2013 r. ${ }^{64}$, w którym uznano, że art. 15 ust. 2 u.r.z.s., w brzmieniu nadanym przez art. 1 pkt 4 lit. a ustawy z dnia 29 października $2010 \mathrm{r}$. o zmianie ustawy o rehabilitacji zawodowej i społecznej oraz zatrudnianiu osób niepełnosprawnych oraz niektórych innych ustaw $\mathrm{w}$ zakresie ${ }^{65}, \mathrm{w}$ jakim uzależnia zastosowanie skróconego czasu pracy do osoby niepełnosprawnej zaliczonej do znacznego lub umiarkowanego stopnia niepełnosprawności od uzyskania zaświadczenia lekarskiego o celowości stosowania skróconej normy czasu pracy, jest niezgodny z art. 2 w związku z art. 69 Konstytucji Rzeczypospolitej Polskiej. W najnowszej literaturze zwraca się uwagę, iż zmniejszanie obciążenia pracą jest ważne w przypadku osób z obniżonymi zdolnościami motorycznymi organizmu. Zmniejszanie uciążliwości pracy nie musi jednak następować tylko przez skrócenie jego czasu. W końcu na skutek nieodpowiedniej organizacji pracy pracownik z niepełnosprawnością może wprawdzie wykonywać pracę krócej, ale nadal w warunkach dużego obciążenia dla zdrowia, co wskazuje na konieczność uzupełniania, a niekiedy nawet zastępowania instrumentów dotyczących organizacji czasu pracy dodatkowymi rozwiązaniami uwzględniającymi indywidualne potrzeby pracowników w procesie wykonywania pracy. Identyfikację tych potrzeb umożliwiają zwłaszcza informacje zawarte w orzeczeniach czy też przeprowadzane badania profilaktyczne ${ }^{66}$.

Pozytywnie należy ocenić regulacje dotyczące urlopów wypoczynkowych i zwolnień od pracy, które pozwalają pracownikom niepełnosprawnym w stopniu znacznym i umiarkowanym korzystać z usług rehabilitacyjnych, medycznych i zaopatrzenia ortopedycznego.

Warto jednak zauważyć, że środowisko osób z niepełnosprawnościami dostrzega również zjawisko tzw. dyskryminacji przez uprzywilejowanie, kiedy to szerokie uprawnienia socjalne obciążające pracodawców postrzegane są niekiedy jako zniechęcające do zatrudniania osób z niepełnosprawnościami ${ }^{67}$.

\footnotetext{
62 E. Staszewska, [w:] Ustawa o rehabilitacji..., s. 370 i n.

63 Por. A. Sobczyk, Refleksje nad zmianami w prawie pracy na przykładzie czasu pracy pracowników niepełnosprawnych, „Praca i Zabezpieczenie Społeczne” 2012, nr 2, s.14 i n.

64 Wyrok TK z dnia 13 czerwca 2013 r., K 17/11, OTK-A-2013/5/58 (Dz.U. z 2013 r. poz. 791).

65 Dz.U. z 2010 r. Nr 226 poz. 1475 z późn. zm.

66 M. Paluszkiewicz, Wolność pracy osób..., s. 318.

67 Społeczny Raport Alternatywny z realizacji Konwencji o prawach osób z niepełnosprawnościami w Polsce, red. J. Zadrożny, Warszawa 2015, s. 50; por. też. P.W. Zawadzki, Praca i zatrudnienie, [w:] Polska droga Konwencji o prawach osób niepełnosprawnych ONZ, Kraków 2008, s. 161 i n.
} 
Konkludując, należy stwierdzić, iż podstawowe znaczenie dla właściwej realizacji wzmożonej ochrony pracy osób niepełnosprawnych ma informowanie pracodawców o niepełnosprawności poprzez przedstawianie stosownych orzeczeń. Potrzebna jest także właściwa postawa pracodawców, którzy będą zainteresowani zatrudnianiem pracowników $\mathrm{z}$ niepełnosprawnościami bez obawy o zwiększanie kosztów związanych z dodatkowymi przywilejami, co winno być z kolei rekompensowane w jak największym zakresie systemem finansowych zachęt. Prymat nad oszczędnościami ze strony pracodawców i funkcjonującymi stereotypami o zmniejszonej wydajności pracy osób niepełnosprawnych, a także obawą przed ujawnieniem orzeczenia przez samych niepełnosprawnych winny wziąć ochrona życia i zdrowia zarówno niepełnosprawnych, jak i pełnosprawnych pracowników.

\section{Akty prawne}

Konwencja ONZ o prawach osób niepełnosprawnych z dnia 13 grudnia 2006 r. (Dz.U. z 2012 r. poz. 1169).

Rozporządzenie Parlamentu Europejskiego i Rady (UE) 2016/679 z dnia 27 kwietnia 2016 r. w sprawie ochrony osób fizycznych w związku z przetwarzaniem danych osobowych i w sprawie swobodnego przepływu takich danych oraz uchylenia dyrektywy 95/46/WE (ogólne rozporządzenie o ochronie danych) (Dz.U. UE L.2016.119.1).

Konstytucja Rzeczypospolitej Polskiej z dnia 2 kwietnia 1997 r. (Dz.U. z 1997 r. Nr 78, poz. 483).

Ustawa z dnia 26 czerwca 1974 r. Kodeks pracy (tekst jedn. Dz.U. z 2019 r. poz. 1040).

Ustawa z dnia 27 czerwca 1997 r. o służbie medycyny pracy (tekst jedn. Dz.U. z 2019 r. poz. 1175).

Ustawa z dnia 27 sierpnia $1997 \mathrm{r}$ o rehabilitacji zawodowej i społecznej oraz zatrudnianiu osób niepełnosprawnych (tekst jedn. Dz.U. z 2020 r. poz. 426).

Ustawa z dnia 17 grudnia 1998 r. o emeryturach i rentach z Funduszu Ubezpieczeń Społecznych (tekst jedn. Dz.U. z 2020 r. poz. 53).

Ustawa z dnia 29 października 2010 r. o zmianie ustawy o rehabilitacji zawodowej i społecznej oraz zatrudnianiu osób niepełnosprawnych oraz niektórych innych ustaw w zakresie (Dz.U. Nr 226, poz. 1475 z późn. zm.).

Rozporządzenie Ministra Pracy i Polityki Socjalnej z dnia 26 września 1997 r. w sprawie ogólnych przepisów bezpieczeństwa i higieny pracy (tekst jedn. Dz.U. z 2003 r. Nr 169, poz. 1650).

Rozporządzenie Ministra Infrastruktury z dnia 12 kwietnia 2002 r. w sprawie warunków technicznych, jakim powinny odpowiadać budynki i ich usytuowanie (Dz.U. z 2019 r. poz. 1065).

Rozporządzenie Ministra Pracy i Polityki Społecznej z dnia 23 grudnia 2014 r. w sprawie zwrotu dodatkowych kosztów związanych z zatrudnianiem pracowników niepełnosprawnych (Dz.U. z 2014 r. poz. 1987). 


\section{Orzecznictwo}

Uchwała SN z dnia 18 kwietnia 2000 r., III ZP 6/00, OSNP 200/20/74.

Wyrok SN z dnia 7 grudnia 2017 r., I PK 334/16, OSNP 2018/9/119.

Wyrok SN z dnia 6 lipca 2005 r., III PK 51/05, OSNP 2006/5-6/85.

Wyrok SN z dnia 3 sierpnia 2016 r., I PK 168/15, LEX nr 2087686.

Wyrok TK z dnia 4 października 2005 r., K 36/03.

Wyrok TK z dnia 13 czerwca 2013 r., K 17/11, OTK-A-2013/5/58 (Dz.U. z 2013 r. poz. 791).

Wyrok WSA w Gorzowie Wielkopolskim z dnia 9 listopada 2017 r., II SA/Go 536/17, LEX nr 2399983.

\section{Literatura}

Brząkowski M., Zatrudnianie niepełnosprawnych, Warszawa 2014.

Dörre-Kolasa D., [w:] Akty wykonawcze prawa pracy. Komentarz, red. K.W. Baran, Warszawa 2016.

Gabler D., Hadław A., Garczyński M., Przystosowanie stanowiska pracy osoby niepełnosprawnej, Warszawa 2010.

Garlicki L., Komentarz do art. 24 Konstytucji, [w:] Konstytucja Rzeczypospolitej Polskiej. Komentarz. Tom I, red. L. Garlicki, M. Zubik, Warszawa 2016, Lex/el.

Giełda M., Pojęcie niepetnosprawności, [w:] Prawno-administracyjne aspekty sytuacji osób niepełnosprawnych $w$ Polsce, red. M. Giełda, R. Raszewska-Skałecka, Wrocław 2015.

Gonera K., Jak obliczać stawkę za godziny nadliczbowe niepełnosprawnego, „Służba Pracownicza" 2007, nr 3.

Gonet W., Wymiar czasu pracy i urlopy osób niepełnosprawnych, „Przegląd Legislacyjny” 2006, nr 2(54).

Góral Z., Prawo do pracy. Studium prawa polskiego w świetle porównawczym, Łódź 1994.

Góral Z., O kodeksowym katalogu zasad indywidualnego prawa pracy, Warszawa 2011.

Grzonka L., Zatrudnianie osób niepełnosprawnych, Warszawa 2010.

Klimkiewicz L., Czas pracy osób niepełnosprawnych, cz. 2, „Służba Pracownicza” 2011, nr 1.

Kuba M., [w:] RODO. Ogólne rozporządzenie o ochronie danych. Komentarz, red. E. Bielak-Jomaa, D. Lubasz, Warszawa 2018.

Kuba M., Staszewska E., Prawo bezrobotnego stażysty do równego traktowania $w$ zatrudnieniu, „Monitor Prawa Pracy” 2019, nr 3.

Kuczyński T., Ochrona pracy, [w:] Z. Kubot et al., Prawo pracy. Zarys wykładu, Warszawa 2008.

Kurowski K., Niepetnosprawność i osoba niepełnosprawna - od medycznego do społecznego modelu niepetnosprawności, [w:] Najważniejsze wyzwania po ratyfikacji Konwencji o Prawach Osób Niepetnosprawnych, red. A. Błaszczak, „Biuletyn RPO. Źródła" 2012, nr 10. 
Liszcz T., Prawo pracy, Warszawa 2009.

Liszcz T., Konstytucyjna zasada ochrony pracy, [w:] G. Uścińska, Prawo pracy. Refleksje i poszukiwania. Ksiega Jubileuszowa Profesora Jerzego Wratnego, Warszawa 2013.

Liszcz T., Konstytucyjne podstawy ochrony pracy, [w:] Prawo ochrony pracy - współczesność i perspektywy rozwoju, red. T. Wyka, M.A. Mielczarek, Warszawa 2017.

Majka P., Rydzewska M., Wieleba I., Zatrudnianie osób niepełnosprawnych. Aspekty prawne i podatkowe, Warszawa 2018.

Paluszkiewicz M., Obowiązek pracodawcy zapewniania osobie niepetnosprawnej niezbędnych racjonalnych usprawnień, [w:] Współczesne problemy prawa emerytalnego, red. T. Bińczycka-Majewska, M. Włodarczyk, Warszawa 2015.

Paluszkiewicz M., [w:] Ustawa o rehabilitacji zawodowej i społecznej oraz zatrudnianiu osób niepetnosprawnych. Komentarz, red. M. Włodarczyk, Warszawa 2015.

Paluszkiewicz M., Ujawnianie orzeczenia o niepełnosprawności a realizacja obowiązku ochrony zdrowia i życia pracownika $z$ niepełnosprawnościa - wybrana problematyka, [w:] Prawo ochrony pracy - współczesność i perspektywy rozwoju, red. T. Wyka, M.A. Mielczarek, Warszawa 2017.

Paluszkiewicz M., Wolność pracy osób z niepełnosprawnościami jako wartość prawnie chroniona, Łódź, 2019.

Roszewska K., Glosa do wyroku Sądu Najwyższego z dnia 3 sierpnia 2016 r. I PK 168/15, OSP 2018/2/19, Lex/el.

Sierpowska I., Pojęcie niepetnosprawności i procedury orzekania o niepełnosprawności, [w:] I. Sierpowska, A. Kogut, Status osoby niepetnosprawnej w polskim systemie pra$w a$, Wrocław 2010.

Sierpowska I., Wstęp, [w:] I. Sierpowska, A. Kogut, Status osoby niepetnosprawnej w polskim systemie prawa, Wrocław 2010.

Sobczyk A., Refleksje nad zmianami w prawie pracy na przykładzie czasu pracy pracowników niepetnosprawnych, „Praca i Zabezpieczenie Społeczne” 2012, nr 2.

Sobczyk A., Prawo pracy w świetle Konstytucji RP. Tom I. Teoria publicznego i prywatnego indywidualnego prawa pracy, Warszawa 2013.

Sobczyk A., Wątpliwości co do użyteczności stosowania pojęcia „ochrona pracy”, [w:] Prawo ochrony pracy - współczesność i perspektywy rozwoju, red. T. Wyka, M.A. Mielczarek, Warszawa 2017.

Społeczny Raport Alternatywny z realizacji Konwencji o prawach osób z niepełnosprawnościami w Polsce, red. J. Zadrożny, Warszawa 2015.

Staszewska E., Szczególne uprawnienia pracownicze osób niepelnosprawnych, [w:] Prawo a niepetnosprawność. Wybrane aspekty, red. M. Bosak, Warszawa 2015.

Staszewska E., [w:] Ustawa o rehabilitacji zawodowej i społecznej oraz zatrudnianiu osób niepełnosprawnych. Komentarz, red. M. Włodarczyk, Warszawa 2015.

Stępniak J., Obowiązki pracodawcy zatrudniajacego pracownika niepelnosprawnego. Komentarz praktyczny, Lex/el. 
Suzdorf J., Przerwy w pracy a przerywany czas pracy, „Służba Pracownicza” 2000, nr 4(1).

Szubert W., Ochrona pracy, [w:] Z. Salwa, W. Szubert, M. Święcicki, Podstawowe problemy prawa pracy, Warszawa 1957.

Szubert W., Uwagi o pojęciu ochrony pracy, [w:] Rozprawy prawnicze. Ksiega pamiątkowa dla uczczenia pracy naukowej Kazimierza Przybyłowskiego, Kraków-Warszawa 1964.

Szubert W., Ochrona pracy. Studium społeczno-prawne, Warszawa 1966.

Szymorek K., Prawo pracodawcy do pozyskiwania informacji o niepetnosprawności pracownika oraz osoby ubiegającej się o zatrudnienie, [w:] A. Giedrewicz-Niewińska, M. Szabłowska-Juckiewicz, Zatrudnianie osób niepetnosprawnych. Regulacje prawne, Warszawa 2014.

Tomaszewska M., Powszechna ochrona pracy, [w:] J. Stelina, Prawo pracy, Warszawa 2014.

Tyśkiewicz-Mazur A., Definicje niepetnosprawności na potrzeby rehabilitacji zawodowej i zatrudnienia, [w:] A. Giedrewicz-Niewińska, M. Szabłowska-Juckiewicz, Zatrudnianie osób niepetnosprawnych. Regulacje prawne, Warszawa 2014.

Wyka T., [w:] K.W. Baran, Kodeks pracy. Komentarz, Warszawa 2018.

Wyka T., Ochrona pracy $w$ dorobku naukowym Profesora Wacława Szuberta, [w:] Prawo ochrony pracy - współczesność i perspektywy rozwoju, red. T. Wyka, M.A. Mielczarek, Warszawa 2017.

Zawadzki P.W., Praca i zatrudnienie, [w:] Polska droga Konwencji o prawach osób niepetnosprawnych ONZ, Kraków 2008. 